\title{
The Exploring Nature of the Assessment Instrument of Five Factors of Personality Traits in the Current Studies of Personality
}

\author{
Seyed Hossein Fazeli \\ Department of English Language Teaching, Abadan Branch, Islamic Azad University, Abadan, Iran \\ E-mail: fazeli78@yahoo.com
}

$\begin{array}{lc}\text { Received: July 28, } 2011 & \text { Accepted: September 20, } 2011 \quad \text { Published: February 1, } 2012 \\ \text { doi:10.5539/ass.v8n2p264 } & \text { URL: http://dx.doi.org/10.5539/ass.v8n2p264 }\end{array}$

\begin{abstract}
The idea which includes the five dimensions of personality has strong dominant in the field of personality studies. In this way, it has enjoyed wide spread popularity in applied organizational context. Although five factors were found in various studies, but its structure has not been accepted generally. The present study aims to explore the current studies regarding nature of five dimensions of personality, its application, its limitations, and the other related characteristics in order to revalue it. The current study confirms the suggested structure of such traits for the study of personality.
\end{abstract}

Keywords: Personality, Five factors personality, Five factors inventory, Big five factors, Big five personality, Five-factor model, NEO-five factor inventory, NEO-PI-R

\section{Introduction}

The concept of personality has a long history, and since 2000 years back personality was researched by many scientists like Cicero and Hippocrates. During its history, it has received considerable attention in the literature up to date as various empirical and theoretical studies.

Generally, high progress has been made toward a consensus on personality structure (Costa \& McCare, 1992; John, 1990; McCare \& John, 1992). It has been conceptualized at different levels of breadth (McAdams, 1992), and each of these levels include our understanding of individual understanding. Moreover, individuals are characterized by a unique pattern of traits. In such case, according to cook (2008), to understand scientifically, it must be interesting in personality.

Psychologically, it is a truism that people are different in many fundamental ways. In such case, there are many variables affect personality such as genetic and environmental factors (Eysenck \& Eysenck, 1985), sex differences (Budaev, 1999; Costa \& McCare, 1992), Culture (Markus \& Kitayama, 1998), and ethnicity (Griffiths, 1991).

Such variables are studied in relationship with personality as topics in different fields such as sociology and anthropology. Such study of variables cause to appear as both theoretical and applied results that even can be as valuable applied theories. For instance, individuals who have same ethnic origin, they may have certain personality characteristics that varied from the other ethnic organs (Griffiths, 1991).

\section{Rievew of Literature}

A large number of researchers attempted to develop definitions for personality, but since natural taxonomies typically have fuzzy definition (Rosch, 1978), and the abstract nature of the concepts in psychology due to some difficulty in defining them empirically (Brown, 2001), there is not a universal definition for the concept of personality. However, there are some dominant definitions in the related literature which are somewhat more agreeable compare the other definitions which are suggested.

There has not been unanimous consensus on definitions of personality traits; the same can be said for their classification. Such lack of unanimous consensus is resulted from many reasons. Moreover, the evaluation of such taxonomies can affect the process of research on personality traits. 
There are many taxonomies of personality traits are suggested in the field of psychology during the history of psychology. The most widely accepted taxonomies are presented as questionnaires (tests) of personality traits. Such questionnaires are used as instruments in order to assess personality of individuals.

There are four most dominant questionnaires of assessment of personality which are designed based on four dominant suggested taxonomies. Firstly, Myers-Briggs Type Indicator (MBTI) is based on the work of Carl Jung, was developed by Isabel Myers and Katharine Cook Briggs. MBTI has been used by researchers more than 60 years (Myers \& Myers, 2009). Moreover, there is claim that it is the most widely used instrument around the world (Myers, McCauuley, Quenk \& Hammer, 1998). However it is criticized by many researchers (Bess \& Havey, 2002; Cowan, 1989; McCare \& Costa, 1989). The personality traits in MBTI are classified as 16 types. The four preferences described by MBTI are Extraversion (E) or Introversion (I); Sensing (S) or iNtuition (N); Thinking (T) or Feeling (F); Judging (J) or Perceiving (P).

The second one belongs to Eysenck. In the beginning, Eysenck suggested two dimensions which were Extraversion/Introversion and Neuroticism/ Emotional Stability. Later, after studying individuals suffering from mental illness, he added a personality dimension; it is called psychoticism(Eysenck, 1992).

The third model of personality is Raymond Cattell's Sixteen Personality Factor. Trait theorist, Raymond Cattell, identified closely related terms as sixteen key personality traits. According to Cattell, these sixteen traits are the source of all human personality. He developed personality questionnaire known as the Sixteen Personality Factor Questionnaire (16PF).

The fourth model of personality which enjoys wide currency is Big Five Theory. This five-factor model of personality represents five core traits that interact to form human personality (McCare \& Costa, 1997).

\section{Instruments to Assess Personality}

Kline (2000) argues that tests to measure personality are based on those aspects of personality they intend to assess. However, there are two types of psychological tests. The first one is "homothetic" in character that face with measuring traits, those dimensions common to individuals, and on how the individuals can be differentiated, such as personality inventories. The second one is "idiographic" in character that deal what is unique and individual to one person, such as projective tests and objective tests.

Generally, in the first type of assessment of personality traits, the relevant literature shows that there are three types of personality measurement tests that more enjoy currency in order to measure one individual's personality as separately or in correlation with various variables such as academic performance. The first one is Eysenck Personality Questionnaire (EPQ). Many studies used EPQ in order to measure personality as separately or in correlation with other variables (Furnham, Jackson \& Miller, 1999; Goh \& Moore, 1977; Jackson \& Lawty-Jones, 1996; Khosravi \& Bigdely, 2008; Pazouki \& Rastegar, 2009).

The second one is Myers-Briggs Type Indicator (MBTI). In many studies, MBTI used in order to measure personality as separately or in correlation with the other variables (Raymond, 1988; Sharp, 2004, 2008; Zimmeran, Johnson, Hoover, Hilton, Heinemann \& Buckmaster, 2006). Moreover, many researchers worked on the MBTI (Beuke, Freman \& Wang, 2006; Boyle, 1995). McCare and Costa (1989) prove that the scales of the MBTI are clearly related to four of five basic factors.

The third one is the questionnaire of Big Five Factors that is one of the most widely used personality assessment around the world. Factor structure resembling the Big Five was identified in numerous sets of variables (Digman \& Inouye, 1986; Goldberg, 1981, 1990; John, 1990; McCare \& Costa, 1985; Saucier \& Goldberg, 1996). In addition, the Big Five Factors personality questionnaire can be as a satisfactory tool to assess the relationship between personality and a number of academic variables (Chamorro-Premuzie, Furnham \& Lewis, 2007). Such measurement is done through some different type of sub-scales and questions but in general, they are used in order to test five dimensions of personality. Those dimensions composing the Big Five Factors are labeled and detailed firstly, Neuroticisms represents the tendency to exhibit poor emotional adjustment, pessimistic, anxious, feeling anxious, nervous, sad, and tense. Secondly, Extraversion represents the tendency to be sociable and assertive, cheerful, active, upbeat, optimistic, activity, assertiveness, positive emotionality. Thirdly, Openness to experiences represents the tendency to imaginative, intellectually curious, imaginative, and artistically sensitive. Fourth, Agreeableness is the tendency to be trusting, compliant, caring, gentle, compassionate, empathic, cooperative, altruism, tender-mindedness, trust, and modesty. Fifth, Conscientiousness represents the tendency to responsible, organized, hard-working, dependable, able to plan, organized, persistent, achievement oriented, purposeful, strong-willed, determined, thinking before acting, delaying gratification, following norms and rules, 
planning, organizing, and prioritizing tasks (as cited in the related literature such as Chamorro-Premuzie, Furnham \& Lewis,2007;Costa \& McCare,1992; John \& Srivastava, 1999).

In the specific definitions, the five dominations in the Big Five are defined as:

"Extraversion implies an energetic approach toward the social and material world ... Agreeableness contrasts a prosocial and communal orientation towards others with antagonism.....Conscientiousness describes socially prescribed impulse control that facilitate task- and goal-directed behavior...Neuroticism contrasts emotional stability and even-temperedness with negative emotionality... Openness to Experiences describes ....the breadth, depth, originality, and complexity of individual's mental and experiential life" (John \& Srivastava, 1999, p30).

It must bear in mind that Extraversion, Conscientiousness, and Neuroticism are measured most reliable, and the other two less (John \& Srivastava, 1999). Moreover, the related literature shows that the researchers researched on extraversion and introversion more than other personality traits (MacIntyer \& Charos, 1996). However, conclusions regarding the studies of extraversion and introversion are varied from each other and they are inconsistent (Busch, 1982; MacIntyer \& Charos, 1996).

The Big Five taxonomy applies integrative function because it represents various systems of personality description (John \& Srivastava, 1999), and factor structures were found in Big Five resembling were found in various studies (Goldberg, 1981, 1990; John, 1990; McCare \& Costa, 1985, 1987; Saucier \& Goldberg, 1996). Moreover, the natural language is as a base for personality in the Big Five personality description (John \& Srivastava, 1999).

Such assessment of five dimensions of personality are done as Five Factors Personality, Five Factors Inventory, Big Five Factors, Big Five Personality, Five-Factor Model, NEO-Five Factor Inventory, NEO-PI-R (Burtonand \& Nelson,2005; Busato, Prins, Elshout \& Hamaker,1998; Caspi, Chajut, Saporta \& Beyth-Marom, 2006; Chamorro-Premuzie \& Furnham ,2003a,2003b;2008; Chamorro-Premuzie, Furnham \& Lewis,2007; Conard,2006; De Fruyt \& Mervielde,1996; Diseth,2003; Farssides \& Woodfield,2003; Furnham \&Chamorro-Premuzic, 2004; Gray \& Watson,2002 ; Liadra, Pullmann \& Allik,2006; Lucas \& Donnellan,2008; McCare \& Terracciano,2005; Mount, Barrick \& Strauss,1994; Oyesoji,2009; Paunonen, 1998 ; Paunonen \& Ashton,2001; Paunonen \& Jackson, 2000; Paunonen \& O’Connor,2007; Rubinstein, 2005;Shokri, Kadivar, Valizadeh \& Sangari,2007; Zhang,2002). The NEO questionnaire includes the best-validates Big Five measures in the type of questionnaire (John \& Srivastava, 1999). Moreover, Costa and McCare (1992) developed 60-item NEO-FFI based on item factor analysis of 1985 version of NEO PI (McCare \& Costa, 1985).

There are various types of research regarding the measurement tests that are used to measure the above-mentioned five dimensions of personality. For example, Block (2001) researched as Five-Factor Approach; Mount and Barrick (1998) researched as Big Five dimensions; Saucier and Ostendorf (1999) researched as Big Five Factors; Costa and McCare (1987) researched on validation of Five-Factor Model regarding instruments and observers; Buchanan, Johnson and Goldberg (2005) researched on online version of Five Factor Personality Inventory; and Harvey, Murry and Markham (1995) compared Big Five Factors with MBTI.

Many studies used Big Five Factors Personality Questionnaire which shows both good internal and external validity (Costa \& McCare, 1992), and even John and Srivastava (1999) used online version of Big Five Personality. They reported internal consistency reliability for all of five dimensions as high. Moreover, evidence for the universality of the Five Factor Model (FFM) is clear across different instruments (McCrae \& Costa, 1997) that Digman and Inouye (1989) state "the domain of personality descriptors is almost completely accounted for by five robust factors" (p.116). In this way, the evidences indicate that Big Five is fairly stable over time (Costa \& McCare, 1988; Digman, 1989), and the scales of Big Five Personality have proven to be useful tool in a number of applied fields. In addition, from other point of view, McCare and Costa (1997) claim that FFM of personality is found in all cultures. Even McCare and John (1992) argue in cross-cultural replication and empirical validation of the Five Factor Model across many methods and instruments. Moreover, John and Srivastava (1999) present “ the Big Five provides a descriptive taxonomy that organizes the myriad natural-languages and scientific trait concepts into a single classificatory framework" (p.33), and "personality taxonomy should provide a systematic framework for distinguishing, ordering, and naming types and characteristics of individuals" (John \& Srivastava, 1999, p.43), In such description, there are various reasons why Big Five Personality dimensions are applied as a workable tool to test personality. However, there is a frequent objection to the Big Five dimensions is lack of inclusive status for all types of personality (Block, 1995; McAdams, 1992). 
The Big Five measures aspects of individual personality by asking questions about behaviors, attitudes, and reactions. It includes groups of questions related to five personality dimensions. The Big Five Personality Questionnaire is based on the Big Five Factor Model of personality whose major proponents are Lewis Goldberg, Paul Costa, and Robert McCare. This theory proposes that five broad dimensions provide complete description of personality.

The NEO-PI, NEO-PI-R and NEO-FFI have been translated into different languages such as Arabic, Chinese, Dutch, French, German, Hebrew, Japanese, Polish (Costa \& McCare, 1992), and McCare and Terracciano (2005) discuss that NEO-PI-R has been translated into 30 languages and almost of them were done by bilingual psychologists familiar to the culture. However, traits in everywhere do not mean that average trait levels need to be universal.

Most research on Big Five has been done based on self-reports and peer ratings (John \& Srivastava, 1999). There are various examples of studies around the world regarding the use of Big Five. Some of these studies are listed below.

Chamorro-Premuzie, Furnham and Lewis (2007) used NEO-FFI personality inventory in their study in order to investigate on 221 British medical students (both female and male, with range age between 20 to 28 , on average 22.67 years old) in UK. They found that Emotional stability, Openness to Experiences, and Agreeableness were associated with deep approach to learning, and they were negatively related to the surface approach. In addition, Conscientiousness was associated with deep and achieving learning approaches.

Liadra, Pullmann and Allik (2006) used NEO-FFI in their study in order to investigate on 3618 students from elementary to secondary school (both female and male, with age range 7to19) in Estonia. They found Openness to experiences, Agreeableness, and Conscientious correlated positively and Neuroticism correlated negatively with grade point average.

Shokri, Kadivar, Valizadeh and Sangari (2007) used Big Five Factor Inventory in their study in order to investigate on 419 university students (both female and male) in Iran. Its factors' reliability in their study were found .64 for Extraversion, .79 for Openness to experiences, .79 for Neuroticism, .55 for Agreeableness, .88 for Conscientiousness. They found that Openness to experiences, Conscientiousness, and Agreeableness have significant positive relationship with deep learning, and Openness to experiences and Conscientiousness have negative relationship with have surface learning. In addition, they found that Neuroticism and Extraversion have significant positive relationship with surface learning.

Oyesoji (2009) used NEO Big Five Factor Inventory in order to investigate on 450 students (both female and male with age range 17 to 21 ) in Nigeria. Its reliability was found .77. He found Neuroticism could predict academic self-efficacy. Moreover, it was found that the Big-Five Factors of personality were positively associated with academic self-efficacy of educationally distressed adolescents.

Caspi, Chajut, Saporta and Beyth-Marom (2006) used Big Five Inventory in order to investigate on 214 university students (both female and male, with age range between 17 to 57 , and on average age 27.6 years old) in Israel. Their study was about comparison of two instructional environments that were classroom vs. Web-Based Instructional Environment (WBIE). A clear difference between two environments was observed. It was found that classroom participants were as extroverted, and non-participants as neurotic.

Busato, Prins, Elshout and Hamaker (1998) used Big Five Factor personality questionnaire in their study in order to investigate on 900 students at university of Amsterdam. They investigated on the relationship between Big Five Factor personality and learning style. Their study shows that there is significant relationship between some of personality dimensions and some other of learning styles.

$\mathrm{Hu}$ (2004) used Big Five Personality Questionnaire in his study in order to investigate on 379 students of hospitality education (both female and male, with age range 19 to 25 , on average 20.88 years old) in Taiwan. Its factors' reliability in his study were found .61 for Extraversion, .80 for Openness to experiences, .85 for Neuroticism, .82 for Agreeableness, .81 for Conscientiousness. He found that different dimensions of Big-five personality traits were positively related to learning motivation, and Openness to experiences is more greater than other dimensions. Moreover, he found that Openness to experiences and Conscientiousness could be as predicators of learning performance.

Chamorro-Premuzie and Furnham (2008) used NEO-PI-R in their study in order to investigate on 158 university students (both female and male, with age range between 18 to 21, and on average age 19.2 years old) in London. They found that academic performance correlated with openness to experiences and conscientiousness. 


\section{Self-report Questionnaires}

A self-report questionnaire is chosen as a basic instrument, because it is possible to use this kind of questionnaire to survey a large number of participants in manner that would be practicing almost impossible using any other method. Questionnaire is used as one of the most widely data-elicitation tool (Gao, 2004). In addition, it is used by many researchers (Bialystok, 1981; Ehrman \& Oxford, 1990; Oxford \& Nyikos, 1989; Ramirez, 1986). If high reliable questionnaires are preferred because we can be sure that, we will get the same result each time we measure the same thing. However if the questionnaire is not reliable, we do not know if the changes in the scores are due to changes in the person we are measuring or to some type of error in testing process.

There are three ways of using self-administered questionnaire instruments. Firstly, using the available questionnaire without any change; secondly, using adapted questionnaire; thirdly, developing new questionnaire.

Based on the availability and characteristics, one researcher will choose one of these questionnaire types. If the same questionnaire has tested for its psychological parameters, it is possible to use it as what it is, and without any change. Nevertheless, since in cross-cultural research, some changes are needed in order to avoid some problems.

\section{General Procedure of Adaptation Instrument of Five Factors of Personality Traits}

In adaptation of Instruments from one language to another in research works, some problems occur, such as the problem of translation one questionnaire to another language (Perera \& Eysenck, 1984), differences in cultures (Ben Porath, 1990).

In the translation of Instrument of Five Factors of Personality Traits, the translation/back translation is one of more effective ways to solve the equivalent concepts of translated and original version of one questionnaire (Behring \& Law, 2000), and one researcher can be ideal translator if she or he is fluent in target language. In such case, there is need to some psychologists who are professional in the related field in order to check the translated and adapted questionnaire from two points of view. Firstly, since the psychologists must be fully proficient in both languages (English and the language that the questionnaire must be translated), they check the translated version of the questionnaire in order to check the consistency with English version of it. Secondly, since the psychologists are professional in related study of the questionnaires, they check the psychometrics of the questionnaire. In such case, after full agreement among the psychologists will be achieved, and the pilot study confirms the items of the Instrument of Five Factors of Personality Traits, it will be administrated.

In the pilot study of Instrument of Five Factors of Personality Traits, after pilot study, one informal discussion with the participants who participate in the pilot study is suggested. In such session of discussion, the comments of the participants will be asked. All the suggested comments will be written as a particular list of comments. Such list must checked by the researcher to categorize its items in different categories. Moreover, such list must be discussed with the psychologists in order to apply them and affect the instrument of the study (Instrument of Five Factors of Personality Traits). In the end, all the suggestions of the psychologists must be applied up to everybody agrees upon. The revised instrument will be shown to some of participants who participated in the pilot study in order to finalize it.

The reason for such procedure it is that the participants should be tested on valid and reliable instruments (Chamot, 2005).

\section{General Limitations of Working with Instrument of Five Factors of Personality Traits}

Since all the education quasi-research deal with living human beings are occur out of laboratory conditions have limitations (Gall, Gall \& Borg, 2003). Generally speaking, there are some limitations inherent in endeavor to conduct any research work on personality assessment. Such limitations are as the results of method (e.g. measurement issues, sampling issues), type of instrumentations(e.g. exclusive reliance on self-report responses to the questionnaires, ambiguity in the questionnaire item wording, response style bias) and so on.

Regarding the issue of questionnaire type of this instrument, although survey studies have been very illuminating and have yielded important results, the first limitation of this study is that measuring of personality traits is done by using questionnaire. Since the questionnaires are self-report and single source of information, it is not clear whether personality traits they actually have. Their response may not be just their beliefs and thoughts that they have about themselves. In such way, in order to investigate students' actual personality traits, it should be some research method to corroborate results of questionnaire. The second, there are may also have been some unclear points in questionnaire itself. "Strongly Agree" to "Strongly Disagree" may have been fuzzy because the interpretation of these scales can change according to context (Hatch \& Brown, 1995), and the vagueness of wording has been another persistent problem in using questionnaire (Gu, Wen $\& W u, 1995)$. The third limitation 
is response biases. As it is known there are three prominent types of response biases, which are social desirable response, acquiescence, and extremely response bias (Herk, Poortinga \& Verhallen, 2004). The fourth issue, difficulty in cross-language research involves translation of the questionnaires. Regarding the limitation related to culture, as Eliason (1995) discuses both culture and language affect the questionnaires. In such way, fifth limitation, many value measurements which are developed in western countries are not success to assess in eastern countries (Matthews, 2000; Schwartz, Malech, Lehmann, Burgess, Harris \& Owens, 2001).

Since longitudinal research is more complicated and much slower, such type of study (use Instrument of Five Factors Personality) in group is chosen by many researchers. Regarding the limitations related to statistical method, there is an important issue in the statistical procedures, that it is the reliability estimates of internal consistency may not be appropriate to measure something that could fluctuate in short period of time as what is used in the most of studies. The test-retest reliability measure is better indicator of reliability in this type of research.

Generally speaking, one of the problematic issues that can be as a limitation is rarely possible to adequately control for all variables in any natural research.

\section{Conclusion}

The idea of major dimensions include much of personality is long standing (Norman, 1963). Even there is belief that the Big Five dimensions have substantial genetic basis (Loehline, McCare, Costa \& John, 1998). In addition, Digman and Inouye (1989) state "the domain of personality of personality descriptors is almost completely accounted for by five robust factors" (p.116). In addition, Big Factor Inventory has enjoyed wide spread popularity in applied organizational context. In this way, the development of Big Five personality framework (Costa \& McCrae, 1992; Goldberg, 1990) can be conceptualized in terms of five basic dimensions. Despite the Five Factors Inventory enjoys international use, but the Big Five structure has not been accepted generally (Block, 1995; Eysenck, 1992, 1997; McAdams, 1992).

There are various methods to collect data, such as survey tools and written questionnaire (Gu \& Johnson, 1996; Fan,2003), interview ( $\mathrm{Gu}$ 2003; Parks \& Raymond,2004), think-aloud or verbal reports (Anderson \& Vandergrift,1996; Goh,1998; Nassaji,2003), diaries or dialogue journal (Carson \& Longhini,2002;Oxford, Lavine, Felkins, Hollaway \& Saleh, 1996), recollective narratives (Oxford, Lavine, Felkins, Hollaway \& Saleh, 1996). Such measurements are used in the single form of method (separately) or as component methods (single set of methods) based on nature and goals of research works. For example, Griffiths (2004) used self-report and interview in her research work. Rubin (1975) did by means of observing students in classrooms, talking to good language learners, and eliciting observation from teachers.

Every one of these methods has specific structure and characteristics. For instance, according to Nunan (1992), interview vary from structured, through semi-structured to un- structured, and as Naiman, Frohlich, Stern and Todesco (1978) claim "the interview proved to be a useful research technique" (p.35). Alternatively, the multiple-methods procedure has specific characteristics. For instance, it is used whenever the time is available. When the time is restricted, researcher should use the most reliable and valid strategy assessment measure (Oxford, 1996). In this way, Cohen (1998), McDonough (1995), O'Malley and Chamot (1990) claim that each kind of data collection has its own limitation.

Since usually some items of Instrument of Five Factors of Personality Traits are vague, and therefore open to differing interpretation based on the different individuals, thereby possibly affecting reliability, it causes to the results, as Gu, Wen and $\mathrm{Wu}(1995)$ state that such results can be "dangerously inadequate and unreliable"(p.7). However, as Dornyei (2003) points out advantages for self-report, as versatility, cost effectiveness, and efficiency in terms of staff and students time and effort, and self-administered questionnaire may have much less interview bias (Gorard,2001).

Although most research has employed multi-data collection (Ellis, 1994), and in order to amplify the quantitative questionnaire data, it is need to employ complementary qualitative data collection as recommended by Chaudron (1986), but as O'Malley and Chamot (1990) point out the results of data collection procedure varied considerably when there are multi-data collection procedures

At last but not least, there is not a method abandoned as what it might be called a baby-and-bathwater type reaction. Still all methods have failed to deliver quit the hoped-for miracles. In this way, methodology alone can never be a solution to find what is searching. Rather it is an aid and suggestion. In addition, in the case of methodology, it is true that we are moving in risky area. Moreover, it is the best when design is dictated by nature of the problem rather than academic fashion and prestige. 


\section{References}

Anderson, N.J., \& Vandergrift, L. (1996). Increasing metacognitive awareness in the L2 classroom by using think-aloud protocols and other verbal report formats. In R. L. Oxford, (Ed.). Language learning strategies around the world: Cross-cultural perspectives (pp.3-18). Honolulu, HI: University of Hawaii Press.

Behling, O. \& Law, K. S. (2000). Translating questionnaires and other research instruments: Problems and solutions. Sage University Papers Series on Qualitative Applications in Social Sciences. 07-131. Thousand Oaks, CA: Sage.

Ben Porath, Y. S. (1990). Cross-Cultural comparison of language learning strategies in the people's republic of China and other countries. In R. L. Oxford (Ed.). Language learning strategies around the world: Cross-cultural perspectives (pp.47-60). Honolulu: University of Hawai'i, Second Language Teaching \& Curriculum Center.

Bess, T. L. \& Harvey, R.J. (2002). Bimodal score distributions and the Myers-Briggs Type Indicator: Fact or artifact? Journal of Personality Assessment, 78, 176-186. http://dx.doi.org/10.1207/S15327752JPA7801_11

Beuke, C. J., Freman, D. G. \& Wang, S. (2006). Reliability and validity of the Myers-Briggs Type Indicator form M when translated into traditional and simplified characters. Presented in Psychological Type and Culture-East \& West: A Multicultural Research Conference, January 6-8 at Honolulu, Hawaii. [Online] Available: http://typeandculture.org/Pages/C_papers06/BeukeChineseRelib.doc.pdf (March 25, 2010)

Bialystok, E. (1981). The role of conscious strategies in second language proficiency. Modern Language Journal, 65, 24-35.

Block, J. (1995). A contrarian view of the five-factor approach to personality description. Psychological Bulletin, 117, 187-215. http://dx.doi.org/10.1037/0033-2909.117.2.187

Block, J. (2001). Millennial contrarianism: The Five-Factor Approach to personality description 5 years later. Journal of Research in Personality, 35, 98-107. http://dx.doi.org/10.1006/jrpe.2000.2293

Boyle, G.L. (1995). Myers-Briggs Type Indicator (MBTI): Some psychometric limitations. [Online] Available: http://epublications.bond.edu.au/cgi/viewcontent.cgi?article=1026\&amp;context=hss_pubs (March 16, 2010)

Brwon, H. D. (2001). Principles of language learning and teaching. Englewood Cliffs, NJ: Prentice Hall.

Buchanan, T., Johnson, J. A. \& Goldberg, L. R. (2005). Implementing a Five-factor Personality inventory for use on the internet. European Journal of Psychological Assessment, 21(2), 115-127. http://dx.doi.org/10.1027/1015-5759.21.2.115

Budaev, S. V. (1999). Sex differences in the Big Five personality factors: Testing an evolutionary hypothesis. Personality and Individual Differences, 26, 801-813. http://dx.doi.org/10.1016/S0191-8869(98)00179-2

Burton, L. J. \& Nelson, L. J. (2005). The relationships between personality, approaches to learning, and academic success in first-year psychology distance education students. [Online] Available: http://eprints.usq.edu.au/3210/1/Burton_Nelson.pdf (March 18, 2010)

Busato, V. V.,Prins, F. J. Elshout, J. J. \& Hamaker, C. (1998). The relation between learning styles, the Big Five personality traits and achievement motivation in higher education. Personality and Individual Differences, 26(1), 129-140. http://dx.doi.org/10.1016/S0191-8869(98)00112-3

Busch, D. (1982). Introversion-extraversion and the EFL proficiency of Japanese students. Language Learning, 32, 109-132. http://dx.doi.org/10.1111/j.1467-1770.1982.tb00521.x

Carson, J. G. \&Longhini, A. (2002). Focusing on learning styles and strategies: A dairy study in an immersion setting. Language Learning, 52(2). 401-438. http://dx.doi.org/10.1111/0023-8333.00188

Caspi, A., Chajut, E., Saporta,K. \& Beyth-Marom, R. (2006). The influence of personality on social participation in learning environments. Learning and Individual Differences, 16, 129-144. http://dx.doi.org/10.1016/j.lindif.2005.07.003

Chamot, A. U. (2005). The cognitive Academic Language Learning Approach (CALLA): An update. In P.A. Richards-Amato \& M.A. Snow (Eds.) Academic success for English language learners: Strategies for K-12 mainstream teachers (pp.87-101). New York: Longman.

Chamorro-Premuzie, T. \& Furnham, A. (2003a). Personality traits and academic examination performance. European Journal of Personality, 17, 237-250. http://dx.doi.org/10.1002/per.473 
Chamorro-Premuzie, T. \& Furnham, A. (2003b). Personality predicts academic performance: Evidence from two longitudinal university samples. Journal of Research in Personality, 37(4), 319-338. http://dx.doi.org/10.1016/S0092-6566(02)00578-0

Chamorro-Premuzie, T. \& Furnham, A. (2008). Personality, intelligence and approaches to learning as predictors of academic performance. Journal of Personality and Individual Differences, 44, 1596-1603. http://dx.doi.org/10.1016/j.paid.2008.01.003

Chamorro-Premuzie, T., Furnham, A. \& Lewis, M. (2007). Personality and approaches to learning predict preference for different teaching method. Learning and Individual Differences, 17, 241-250. http://dx.doi.org/10.1016/j.lindif.2006.12.001

Chaudron, C. (1986). The interaction of quantitative and qualitative approaches to research: A view of the second language classroom. TESOL Quarterly, 20(4), 709-717. http://dx.doi.org/10.2307/3586521

Cohen, A. D. (1998). Strategies in learning and using a second language. Essex, U. K: Longman.

Cook, V. (2008). Second language learning and language teaching. (4 ${ }^{\text {th }}$ ed.). London: Edward Arnold.

Conard, M.A. (2006). Aptitude is not enough: How personality and behavior predict academic performance. Journal of Research in Personality, 40, 339-346. http://dx.doi.org/10.1016/j.jrp.2004.10.003

Costa, P.T. \& McCare, R.R. (1987). Validation of the five-factor model of personality across instruments and observers. Journal of Personality and Social Psychology, 52(1), 81-90. http://dx.doi.org/10.1037/0022-3514.52.1.81

Costa, P.T. \& McCare, R.R. (1988). Personality in adulthood: a six-year longitudinal study of self-reports and spouse ratings on the NEO Personality Inventory. Journal of Personality and Social Psychology, 54(4), 853-863. http://dx.doi.org/10.1037/0022-3514.54.5.853

Costa, P.T. \& McCare, R.R. (1992). Professional Manual for the NEO-PI-R and NEO-FFI. Odessa, FL: Psychological Assessment Resources.

Cowan, D.A. (1989). An alternative to the dichotomous interpretation of Joung's psychological functions: Developing more sensitive measurement technology. Journal of Personality Assessment, 53, 459-471. http://dx.doi.org/10.1207/s15327752jpa5303_4

De Fruyt, F. \& Mervielde, I. (1996). Personality and interests as predictors of educational streaming and achievements. European Journal of Personality, 10, $405-425$. http://dx.doi.org/10.1002/(SICI)1099-0984(199612)10:5<405::AID-PER255>3.0.CO;2-M

Digman, J. M. (1989). Five robust traits dimensions: Development, stability, and utility. Journal of Personality, 57(1), 195-214. http://dx.doi.org/10.1111/j.1467-6494.1989.tb00480.x

Digman, J. M. \& Inouye, J. (1986). Further specification of the five robust factors of personality. Journal of Personality and Social Psychology, 50, 116-123. http://dx.doi.org/10.1037/0022-3514.50.1.116

Diseth, A. (2003). Personality and approaches to learning as predictors of academic achievements. European Journal of Personality, 17, 143-155. http://dx.doi.org/10.1002/per.469

Dornyei, Z. (2003). Questionnaire in second language research. Muhwah, New Jersey: Lawrence Erlbaum.

Ehrman, M. \& Oxford, R. L. (1990). Adult language learning styles and strategies in an intensive training setting. Modern Language Journal, 74(3), 311-327. http://dx.doi.org/10.1111/j.1540-4781.1990.tb01069.x

Eliason, P.A. (1995). Difficulties with cross-cultural learning-style assessment. In J.M. Reid (Ed.). Learning styles in the ESL/EFL classroom (pp.19-33). New York: Heinle \& Heinle Publishers.

Ellis, R. (1994). The study of second language acquisition. Oxford: Oxford University Press.

Eysenck, H.J. (1992). Four ways five factors are not basic. Personality and Individual Differences, 13, 667-673. http://dx.doi.org/10.1016/0191-8869(92)90237-J

Eysenck, H. J. (1997). Personality and experimental psychology: The unification of Psychology and the possibility of a paradigm. Journal of Personality and Social Psychology, 73, 1224-1237. http://dx.doi.org/10.1037/0022-3514.73.6.1224

Eysenck H.J. \& Eysenck, M. W. (1985). Personality and individual differences: a natural science approach. New York: Plenum Press. http://dx.doi.org/10.1007/978-1-4613-2413-3 
Fan, M. Y. (2003). Frequency of use perceived usefulness, and actual usefulness of second language vocabulary strategies: A study of Hong Kong learners. Modern Language Journal, 87(2), $222-241$. http://dx.doi.org/10.1111/1540-4781.00187

Farssides, T. \& Woodfield, R. (2003). Individual differences and undergraduate academic success: The roles of personality, intelligence, and application. Personality and Individual Differences, 34, 1225-1243. http://dx.doi.org/10.1016/S0191-8869(02)00111-3

Furnhum, A., \& Chamorro-Premuzic, T. (2004). Personality and intelligence as predictors of statistics examination grades. Personality and Individual Differences, 37, $943-955$. http://dx.doi.org/10.1016/j.paid.2003.10.016

Furnham, A. \& Jackson, C. Miller, T. (1999). Personality, learning style and work performance. Personality and Individual Differences, 27(6), 1113-1122. http://dx.doi.org/10.1016/S0191-8869(99)00053-7

Gall, M.D., Gall, J.P. \& Borg, W.R. (2003). Educational Research: An Introduction. (7 ${ }^{\text {th }}$ ed.). Boston: Allyn and Bacon.

Gao, X. (2004). A critical review of questionnaire use in learner strategy research. Prospect, 19(3), 3-14.

Gray, E. K. \& Watson, D. (2002). General and specific traits of personality and their relation to sleep and academic performance. Journal of Personality, 70, 177-206. http://dx.doi.org/10.1111/1467-6494.05002

Globerg, L.R. (1981). Language and individual differences: The search for universals in personality lexicons. In L. Wheeler(Ed.). Review of personality and social psychology (Vol. 2, pp.141-165). Beverly Hills, CA: Sage.

Globerg, L.R. (1990). An alternative description of personality: The Big Five factor structure. Journal of Personality and Social Psychology, 59, 1216-1229. http://dx.doi.org/10.1037/0022-3514.59.6.1216

Goh, C. M. (1998). How ESL learners with different listening abilities use comprehension strategies and tactics. Language Teaching Research, 2(2), 124-147.

Goh, D. \& Moore, C. M. (1977). Personality and academic achievement in three educational levels. Paper presented at the annual meeting of the American Educational Research Association (New York, April 4-8). [Online] Available: http://www.eric.ed.gov/ERICWebPortal/search/detailmini.jsp?_nfpb=true\&_\&ERICExtSearch_SearchValue_0= ED143907\&ERICExtSearch_SearchType_0=no\&accno=ED143907 (March16, 2010)

Gorard, S. (2001). Quantitative methods in educational research: The role of numbers made easy. London: Continuum.

Griffiths, C. (1991). Personality and second-language learning: Theory, research, and practice. [Online] Available: http://www.eric.ed.gov/PDFS/ED367167.pdf (March 10, 2011)

Griffiths, C. (2004). Language learning strategies: Theory and research. Occasional Paper (1). [Online] Available: http://www.eric.ed.gov/PDFS/ED367167.pdf (March 18, 2010)

Gu, P. Y. (2003). Fine brush and freehand: The vocabulary-learning art of two successful Chinese EFL learners. TESOL Quarterly, 37(1), 73-104. http://dx.doi.org/10.2307/3588466

Gu, P. Y. \& Johnson, R. K. (1996). Vocabulary learning strategies and language learning outcomes. Language Learning, 46(4), 643-679. http://dx.doi.org/10.1111/j.1467-1770.1996.tb01355.x

Gu, P. Y., Wen, Q. \& Wu, D. (1995). How often is Often? Reference Ambiguities of the Likert-scale in Language Learning Strategy Research. Occasional Papers in English Language Teaching, vol.5. ELT Unit, Chinese University of Hong Kong, 19-35.

Harvey, R.J. Murry, W. D. \& Markham, S.E. (1995). A "Big Five" scoring system for the Myers-Briggs Type Indicator. Paper Presented in Annual Conference of the Society for Industrial and Organizational Psychology, Orlando. [Online] Available: http://harvey.psyc.vt.edu/Documents/BIGFIVE.pdf (March 18, 2010)

Hatch, E. \& Brown, C. (1995). Vocabulary, semantics, and language education. Cambridge: Cambridge University Press.

Herk, V.P., Poortinga, Y. H. \& Verhallen, T. M.M. (2004). Response style in rating scales: Evidence of method bias in data from six EU countries. Journal of Cross-Cultural Psychology, 35(3), $346-360$. http://dx.doi.org/10.1177/0022022104264126 
$\mathrm{Hu}, \mathrm{M}$. L. (2004). The relationship between big five personality traits, learning motivation and learning performance of the hospitality students in taiwan.2004 Asia Pacific Tourism Association (APTA) Conference. [Online] Available: http://www.ntnu.edu.tw/acad/docmeet/a8/a802.doc_March 18, 2010)

Jackson, C. \& Lawty-Jones, M. (1996). Explaining the overlap between personality and learning style. Personality and Individual Differences, 20(3), 293-300. http://dx.doi.org/10.1016/0191-8869(95)00174-3

John, O. P. (1990). The Big Five Factor taxonomy: dimensions of personality in the nature language and in the questionnaire. In L.A. Pervin(Ed.). Handbook of Personality: Theory and Research (pp.66-100). New York: Guilford Press.

John, O. P. \& Srivastava, S. (1999). The big Five taxonomy: History, measurement and theoretical perspectives. In L.A. Pervin \& O. P. John (Eds.). Handbook of Personality: Theory and research. New York: Guilford. [Online] Available: http://pages.uoregon.edu/sanjay/pubs/bigfive.pdf (March 20,2010)

Khosravi, M. \& Bigdely, I. (2008). The relationship between personality factors and test anxiety among university students. Journal of Behavioral Sciences, 2(1), 13-24.

Kline, P. (2000). The handbook of psychological testing. ( $2^{\text {nd }}$ ed.). London: Rutledge.

Liadra, K., Pullmann, H. \& Allik, J. (2006). Personality and intelligence as predictors of academic achievement: A cross-sectional study from elementary to secondary school. Personality and Individual Differences, xxx, 1-11.

Loehline, J.C., McCare, R.R., Costa, P. T., Jr. \& John, O. P. (1998). Heritabilities of common and measure-specific components of the Big Five personality factors. Journal of Research in Personality, 32, 431-453. http://dx.doi.org/10.1006/jrpe.1998.2225

Lucas, M. B. \& Donnellan, R. E. (2008). Age differences in the big five across the life span: evidence from two national Samples. Psychol Agin, 23(3), 558-566. http://dx.doi.org/10.1037/a0012897

McAdams, D. P. (1992). The five-factor model in Personality: A critical appraisal. Journal of Personality, 60, 329-361. http://dx.doi.org/10.1111/j.1467-6494.1992.tb00976.x

MacIntyre, P. D. \& Charos, C. (1996). Personality, attitudes, and affect as predictors of second language communication. Journal of Language and Social Psychology, 15(1), 3-26. http://dx.doi.org/10.1177/0261927X960151001

Markus, H.R. \& Kitayama, S. (1998). The cultural psychology of personality. Journal of Cross Cultural Psychology, 29(1), 63-87. http://dx.doi.org/10.1177/0022022198291004

Matthews, B. M. (2000). The Chinese value survey: An interpretation of value scales and consideration of some preliminary results. International Educational Journal, 11(2), 117-126.

McCare, R.R. \& Costa, P.T. Jr. (1985). Updating Norman's adequate taxonomy: Intelligence and personality dimensions in natural language and in questionnaires. Journal of Personality and Psychology, 49, 710-721. http://dx.doi.org/10.1037/0022-3514.49.3.710

McCare, R.R. \& Costa, P.T. Jr. (1987). Validation of the five-factor model of personality across instruments and observers. Journal of Personality and Social Psychology, 52, 81-90. http://dx.doi.org/10.1037/0022-3514.52.1.81

McCare, R.R. \&Costa, P.T. Jr. (1989). Reinterpreting the Myers-Briggs Type Indicator from the perspective of the five-factor model of personality. Journal of Personality, 57, 17-40. http://dx.doi.org/10.1111/j.1467-6494.1989.tb00759.x

McCare, R.R. \& Costa, P.T. Jr. (1997). Personality trait structure as a human universal. American Psychologist, 52, 509-516. http://dx.doi.org/10.1037/0003-066X.52.5.509

McCare, R.R. \& John, O. P. (1992). An introduction to the Five-Factor Model and its application. Journal of Personality, 60(2), 175-215. http://dx.doi.org/10.1111/j.1467-6494.1992.tb00970.x

McCare, R. R. \& Terracciano, A. (2005). Universal futures of personality traits from the observer perspective: Data from 50 cultures. Journal of Personality and Social Psychology, 88(3), 547-561. http://dx.doi.org/10.1037/0022-3514.88.3.547

McDonough, S. H. (1995). Strategy and skill in learning a foreign Language. London: Aronold.

Mount, M. K. \&Barrick, M. R. (1998). Five reasons why the big five article has been frequently cited. Personality Psychology, 51, 849-857. http://dx.doi.org/10.1111/j.1744-6570.1998.tb00743.x 
Mount, M. K., Barrick, M. R. \& Strauss, J.P. (1994). Validity of observer ratings of the Big Five Personality Factors. Journal of Applied Psychology, 79(2), 272-280. http://dx.doi.org/10.1037/0021-9010.79.2.272

Myers, I. B., McCauuley, M. H., Quenk, N. L. \& Hammer, A. L. (1998). MBTI manual: A guide to the development and use of the Myers-Briggs Type Indicator ( $\left.3^{\text {rd }} \mathrm{ed}\right)$. Palo Alto: Consulting Psychological Press.

Myers, P. B. \& Myers, K. D. (2009). Myers-Briggs Type Indicator, interpretive report. [Online] Available: https://www.skillsone.com/Pdfs/smp261144.pdf (March 10, 2010)

Naiman, N., Frohlich, M., Stern, H. \& Todesco, A. (1978). The good language learner. Research in Education series. No.7. Toronto: The Ontario Institute for Studies in Education.

Nassaji, H. (2003). L2 vocabulary learning from context: Strategies, knowledge sources, and their relationship with success in L2 lexical inferencing. TESOL Quarterly, 37(4), 645-670. http://dx.doi.org/10.2307/3588216

Norman, W. T. (1963). Toward an adequate taxonomy of personality attributes: replicated factor structure in per nomination personality ratings. Journal of Abnormal and Social Psychology, 66, 574-583. http://dx.doi.org/10.1037/h0040291

Nunan, D. (1992). Research methods in language learning. Cambridge: Cambridge University Press.

O'Malley, J. M. \& Chamot, A. U. (1990). Learning Strategies in second language acquisition. Cambridge: Cambridge University Press.

Oxford, R. L. (1996). Employing a questionnaire to assess the use of language learning strategies. Applied Language Learning, 7(1\& 2), 25-45.

Oxford, R. L., Lavine, R. Z., Felkins, G., Hollaway, M.E. \& Saleh, A. (1996). Telling their stories: language students use diaries and recollection. In R. L. Oxford (Ed.). Language learning strategies around the world: Cross-cultural perspectives (pp.19-34). Honolulu, HI: University of Hawaii Press.

Oxford, R. L. \& Nyikos, M. (1989). Variables affecting choice of language learning strategies by university students. Modern Language Journal, 73(3), 291-300. http://dx.doi.org/10.1111/j.1540-4781.1989.tb06367.x

Oyesoji, A. A. (2009). Measured influence of Big-Five Factor and gender as correlates of academic self-efficacy of educationally distressed adolescents in Ibadan, Nigeria. The African Symposium: An Online Journal of African Educational Research Network, 9(2), 20-28.

Parks, S. \& Raymond, P.M. (2004). Strategy use by non-native English speaking students in an MBA program: Not business as usual. Modern Language Journal, 88(3), 374-389. http://dx.doi.org/10.1111/j.0026-7902.2004.00235.x

Paunonen, S. V. (1998). Hierarchical organization of personality and prediction of behavior. Journal of Personality and Social Psychology, 74, 538-556. http://dx.doi.org/10.1037/0022-3514.74.2.538

Paunonen, S. V. \& Ashton, M. C. (2001). Big Five Factors and facets and the prediction of behavior. Journal of Personality and Social Psychology, 81(3), 524-539. http://dx.doi.org/10.1037/0022-3514.81.3.524

Paunonen, S. \& Jackson, D. N. (2000). What Is Beyond the Big Five? Plenty! Journal of Personality, 65(5), 821-835. http://dx.doi.org/10.1111/1467-6494.00117

Paunonen, S. V. \& O'Connor, M. C. (2007). Big Five personality predictors of post-secondary academic performance. Personality and Individual Differences, 43, 971-990. http://dx.doi.org/10.1016/j.paid.2007.03.017

Perera, M. \& Eysenck, S. B. G. (1984). A Cross-cultural Study of Personality: Sri Lanka and England. Journal of Cross Cultural Psychology, 15(3), 353-371. http://dx.doi.org/10.1177/0022002184015003007

Ramirez, A.G. (1986). Language learning strategies used by adolescents studying French in New York schools. Foreign Language Annals, 19(2), 131-141. http://dx.doi.org/10.1111/j.1944-9720.1986.tb03108.x

Pazouki, M. \& Rastegar, M. (2009). Extraversion-Introversion, shyness, and EFL proficiency. Psychological Research, 12(1\&2), 78-91.

Raymond, M. (1988). Personality preferences and foreign language learning. Modern Language Journal, 72(4), 389-401. http://dx.doi.org/10.1111/j.1540-4781.1988.tb04198.x

Rosch, E. (1978). Principles of categorization. In E. Rosch \& B. B. Lloyd (Eds.). Cognition and categorization (pp.27-48). Hillsdale, NJ: Erlbaum.

Rubin, J. (1975). What the 'good language learners' can teach us. TESOL Quarterly, 9(1), 41-51. http://dx.doi.org/10.2307/3586011 
Rubinstein, G. (2005). The Big Five among male and female students of different faculties. Personality and Individual Differences, 38, 1495-1503. http://dx.doi.org/10.1016/j.paid.2004.09.012

Saucier, G. \& Goldberg, L. R. (1996). Evidence for the Big Five in analyses of familiar English personality adjectives. European Journal of Personality, 7, 1-17.

Saucier, G. \& Ostendorf, F. (1999). Hierarchical subcomponents of the Big Five Personality Factors: A Cross-language replication. Journal of Personality and Social Psychology, 76(4), 613-627. http://dx.doi.org/10.1037/0022-3514.76.4.613

Schwartz, S. H., Malech, G., Lehmann, A., Burgess, S., Harris, M. \& Owens, V. (2001). Extending the cross-cultural validity of the theory of basic human values with a different method of measurement. Journal of Cross-Cultural Psychology, 32(5), 519-542. http://dx.doi.org/10.1177/0022022101032005001

Sharp, A. (2004). Language learning and awareness of personality type in Chinese setting. Asian EFL Journal, 6 (2), 1-13.

Sharp, A. (2008). Personality and second language learning. Asian Social Science, 4(11), 17-25.

Shokri, O., Kadivar, P., Valizadeh, F. \& Sangari, A. K. (2007). Role of personality traits and learning approaches on academic achievements of university students. Psychological Research, 9(3\&4), 65-84.

Zhang, L. (2002). Does the big five predict learning approaches? Personality and Individual Differences, 34(8), 1431-1446. http://dx.doi.org/10.1016/S0191-8869(02)00125-3

Zimmerman, A. P., Johnson, R.G., Hilton, J. W., Heinemann, P. H. \& Buckmaster, D. R. (2006). Comparison of personality types and learning styles of engineering students, agricultural systems management students, and faculty in an agricultural and biological engineering department. [Online] Available: https://engineering.purdue.edu/ABE/People/Papers/dennis.buckmaster.1/personality.pdf (March 16, 2010) 